\title{
5. Ciphers in Hungary: the source material
}

\subsection{Frameworks of data collection}

A historian of early modern Hungary, Ágnes R. Várkonyi examined the causes of the "particularly widespread" practices of cryptography in the region. ${ }^{1}$ It is hard to judge how far her impressions were right compared to the source material of neighboring countries, because there is no systematic study on the Polish, Czech and Austrian enciphered source materials in the early modern period, and prior to the present monograph, there was no general overview about the Hungarian sources, either. However, as will be evident in the following sub-chapter, the percentage of surviving code tables and ciphered messages is considerably high, my - far from being confirmed - impressions are similar to those of Várkonyi.

Although it is neither necessary nor possible to summarize the history of Hungary in the sixteenth-seventeenth centuries here, ${ }^{2}$ it is worth pointing out that this high percentage of enciphered sources is by no means surprising in light of Hungary's political history. This region became a clash zone in these centuries where Christian and Ottoman armies fought, Western culture was confronted by Islamic culture, Catholicism was challenged by the Reformation, and, to a certain degree, Western Christianity met Eastern Christianity.

Hungary, covering the whole of the Carpathian Basin, was seen by contemporaries as a powerful and rich country in the fifteenth and early sixteenth centuries until 1526, when it was first defeated and then, after the fall of its capital, Buda, in 1541, partly occupied by the Ottoman Empire. Subsequently, as one historian has recently put it, Hungary became "a complicated set of lands caught up in an intricate network of alliances, belonging to and claimed by several ruling houses and dynasties." ${ }^{3}$ As a result of a series of internal fights, the kingdom became divided into three. Its central part remained occupied by the Ottoman sultan until the end of the seventeenth century. Its western and northern regions continued their existence

$1 \quad$ Várkonyi, "A tájékoztatás hatalma," 9 és 27.

2 For an overview of the sixteenth-century history of Hungary, see Géza Pálffy, The Kingdom of Hungary and the Habsburg Monarchy in the Sixteenth Century (Boulder, CO: Center for Hungarian Studies and Publications, Inc., 2009).

3 Dóra Bobory, The Sword and the Crucible: Count Boldizsár Batthyány and Natural Philosophy in Sixteenth-Century Hungary (Newcastle upon Tyne: Cambridge Scholars Press, 2009), 10. 
as the Kingdom of Hungary under the Habsburg kings but, due to its geographical situation, became a permanent battlefield between the Turkish and Christian armies. And third, the Principality of Transylvania started enjoying a limited independence as a vassal state of the Ottoman Empire and ruled by the so-called Prince of Transylvania.

Borders were constantly changing and a large part of the population lived in the border regions. ${ }^{4}$ In this unstable, hence eventful region it was especially important to hide and discover diplomatic, military, scientific and religious secrets. Hungary's richness in enciphered sources makes it an outstanding sample for the study of the social history of secrecy. Other geographic and political areas remain to be revealed by further research, and I hope my studies may offer a helpful example.

But what does "the early modern Hungarian source material" refer to precisely? Where are the frontiers of Hungary, and where are the limits of the early modern period? It is neither possible, nor necessary to draw exact lines, it is, nonetheless, possible to give the rough space and time coordinates for the collection of the sources.

Chronological boundaries are easier to deal with. While the history of secrecy obviously does not conform to political eras and their boundaries, the spread and use of the homophonic cipher do mark the two centuries of the early modern period rather well. They replace monoalphabetic ciphers (which though do not completely disappear until 1700) around the third decade of the sixteenth century to be widely used in Hungary's diplomacy until they too give way to even more complex methods (extensive code books) in the eighteenth century. The use of cryptography in Hungary reaches its summit in the time of the Rákóczi freedom fight (1703-1711) both regarding its quality and its quantity - mainly because prince Rákóczi led intensive and independent foreign policy. Partly due to a quieter political situation, there is a radically decreased number of ciphers surviving from the second decade of the eighteenth century. In this way, therefore, the source material marks its own boundaries from 1526 to 1711 .

Geographical coordinates prove to be less self-evident, and give way to endless debates. All studies of this kind face these obstacles, because it is impossible to build up a perfectly sound selection system. As a guideline, effort was made to be practical in this research:I regarded all editions and secondary sources as potential sources for my studies that were on the history of Hungary, i. e. that are traditionally regarded as such by scholars in research and education (and not the least by library catalogs). The most important collections 
of Hungarian history provided the source material: the National Archives of Hungary, the Manuscript Collection of the National Széchényi Library, the Ráday Archives, the Military Archives of Hungary, the Manuscript and Rare Books Collection of the University Library of ELTE, and the Hungarica, Turcica and Polonica collections of the Haus-, Hof- und Staatsarchiv in Vienna. When doubt arose about a source, I tended to be more inclusive than exclusive. I included the code keys of the correspondence of Ferdinand I and Charles V, kept in the National Széchényi Library, and the letters of the Constantinople envoy of the Habsburg Emperor kept in the Manuscript and Rare Books Collection of the University Library of ELTE. Even though these correspondences did not necessarily discuss matters related to Hungary, I aimed at giving as wide a picture of the sources found in Hungary's archives as possible. I did not, however, include all the code keys of the Saatskanzlei in Vienna. They may be all from Emperor's capital and connected to the Habsburg's diplomacy, but my focus was on cipher collections directly connected to Hungarian history.

Whether a particular cipher key or ciphered message is included in the list of sources or not is an important issue, more important is that the background of a source should be taken into account on all occasions before being used in an argument. For example, the code keys of Andreas Dudith, envoy from Habsburg Emperor Maximilian to the Polish king, have been included in the database, one has to remember, however, that these do not enable us to draw conclusions about the development of 'Hungarian' cryptography, since they only talk about the diplomacy of the Habsburgs, in which a Hungarian nobleman happened to take part.

Obsession about setting sharp geographical boundaries should be avoided also because general tendencies of the history of cryptography - as we will see - are rarely modified by the appearance or exclusion of a new source.

\subsection{General description of the sources}

The sources relevant to the history of cryptography in early modern Hungary are scattered in the archives, mostly unidentified and unpublished. Catalogs often fail to mention that a few paragraphs of a text are written in a cipher.

A few code key collections containing dozens of claves from the history of Habsburg diplomacy, Hungarian family correspondences, and anti-Habsburg uprisings, however, are exceptions to the rule. These were probably placed in a particular fascicle or fond, or under a call number because their onetime collector must have thought that sources of one kind (most typically 
one-page documents) belong together and should be kept in one specific place. The folder collecting the nineteenth-century copies of Antal Gévay in the Manuscript Collection of the National Széchényi Library contains almost fifty Hungarian-related sixteenth-century code keys of the Habsburg diplomacy. ${ }^{5}$ The Staatskanzlei sources of the Haus-, Hof- und Staatsarchiv of Vienna contain several hundred keys (that Gévay may also have used) in rough alphabetical order. ${ }^{6}$ This exceptionally rich collection, only partially related to Hungarian history, sketches beautifully the four hundred years of Habsburg diplomacy. ${ }^{7}$ Ten claves of Mihály Teleki are found in the National Archives of Hungary among the materials of the Teleki family archives of Marosvásárhely (Targu Mures, Romania). ${ }^{8}$ Twenty-two code keys and five ciphered letters, captured in the mop-up of the Wesselényi movement, are also gathered in Vienna. ${ }^{9}$ The cipher tables of Rákóczi's freedom-fight can be found under three call numbers, two of which refer to the documents of Rákóczi that he took with him into exile. These are kept in the National Archives of Hungary, and luckily survived the big fire of 1956 that happened to decimate exactly the Rákóczi's documents. ${ }^{10}$ The third call number refers to the documents of Pál Ráday in the Ráday Archives." There are approxx imately one hundred thirty keys under these three headings, but many of them are in duplicates, so the actual number of different keys is considerably lower. Smaller collections containing fewer than ten keys can be found in the Mednyánszky family archives from the correspondence of György Rákóczi II and Jónás Mednyánszky ${ }^{12}$ and among the letters of Pál Esterházy, also in the National Archives of Hungary. ${ }^{13}$

Apart from these concentrated collections of cipher keys, it is generally true for many other keys and the letters themselves that one needs a lot of effort, good luck, and the help of other researchers to be able to identify them. That is why, the nearly three hundred code keys and almost one thousand six hundred letters consulted for this monograph are not a mere addition to the study, but the result of the most laborious part of my research. Future studies will hopefully complete, correct and benefit from the list of sources compiled.

9 ÖStA HHStA Ung Act. Spec. Fasc. 327. Konv. D. Chiffres 1664-1668.

10 MNL OL G 15 Caps. C. Fasc 43 and 44.

11 Ráday Archives C64-4d2-25.

12 MNL OL P 497 Mednyánszky family, 3. fasc.

13 MNL OL P 125 No. 119772. 
A peculiarity of the region is the multitude of languages used in the sources. The powerful and long-lasting presence of Latin in the early modern period in all of the Central European region is widely known. While the national languages were gaining strength, Latin remained central for a long time. ${ }^{14}$ It was the language of home and foreign affairs (in the Hungarian Diet, for example, or in important peace treaties) and science (Gauss wrote his publications in Latin as late as the nineteenth century). Even commoners spoke Latin sometimes (rumor has it that when Henry Valois arrived in Poland in 1573 to take its throne, he was welcomed by Latin-speaking innkeepers). Latin was sometimes even used even by people arguing for the use of national languages. It is no surprise that ciphered diplomatic and military correspondence was written in Latin too. German was common in the countries of the Habsburg empire - diplomats and captains of German origin naturally liked to write in their mother tongue, in the same way as Hungarian was preferred by Hungarian nobles among themselves. Curiously enough, even the pasha of Buda used Hungarian for decades in his Hungary-related correspondence with the governing bodies of the Habsburgs, excluding the Hungarians themselves from this communication. Spies, typically of Serbian and Bosnian origin, sent their reports in Italian from Constantinople or Ragusa via Venice to Vienna, while the Italian language was gaining importance as the language of the homeland of diplomacy and cryptography. Turkish was present due to the Ottoman occupation. French was also surprisingly popular, even dominant at times, and not only when the leader of the anti-Habsburg appraisal, Ferenc Rákóczi II, was negotiating with his ally, Louis XIV, but also in his letters to his Polish allies.

An important question is how the quantity of the sources presented below relate to the full body of extant manuscripts. This ratio can be best examined according to the three different source types: the cipher tables, the published and the handwritten enciphered documents.

In case of the cipher tables, I was aiming at giving a full picture. This type of source is typically hand-written, it can be found in manuscript collections and archives. Few of them have been published, while one part of the actually published tables are in fact reconstructed, that is, they did not survive as manuscripts, but are based on the enciphered letters that have been broken by the given historian. While I cannot be completely sure that I have found every extant key in the archives (my account is constantly growing, though at a slower pace), in my estimate probably about eighty percent of the extant materials have been taken into account.

14 Peter Burke, “'Heu domine, adsunt Turcae': a Sketch for a Social History of Post-Medieval Latin," in idem, The art of conversation (Cambridge, Polity Press, 1993): 34-65. 
Similarly, the aim was to collect all enciphered letters to be found in source publications and secondary literature. Eighty percent completion has presumably been achieved. It was useful to have a big part of the literature in digital form, especially the source publications of the nineteenth century. These editions are outdated and not always reliable, yet, they are useful for several reasons. A large number of the original letters are now missing, one only knows about them from the publications. Also these digitized sources can be used well for quantitative studies on the mechanisms of secrecy, explicit statements related to the practice of cryptography can be easily identified in them.

As for the original, handwritten documents, I have collected more than a thousand of them, sufficient enough to support the arguments about the historical tendencies related to cryptography. To estimate the total number of enciphered letters kept in the archives is not possible, only approximations are feasible through specific examples. In an archival fascicle related to a military conflict, each and every letter might have been enciphered, but this ratio is more the exception than the rule. In the archive of a family that was involved in high politics, every hundredth letter was enciphered. In other types of archival sources, however, this percentage could be smaller. Having examined numerous archival funds containing primarily diplomatic and private letters, I gathered the impression that on an average as much as one percent of the extant sources are partially or completely enciphered. This may not sound a large quantity at first. However, if we imagine how daunting a task would be to collect one percent of the complete early modern literature, it becomes evident that this is a vast sum. If this estimate is right, collecting the relevant source material is the undertaking of several future generations, of which my studies can only aspire to serve as the basis. Nevertheless, I hope that the sources to be discovered later will only specify, and not modify all that is going to be outlined in the following.

\section{5·3. Cipher keys}

\subsubsection{The structure of the tables}

A precondition of enciphered messaging, at least in the sixteenthseventeenth centuries, was that both corresponding partners own a copy of the code table, in other words, the cipher key or clavis. It ensures that the encryption and the decryption are symmetric, that is, the addressee reads exactly what the sender wrote. 
Cipher tables are usually one-page documents. They are usually large sheets, sometimes smaller scraps of paper, even more rarely, parchment sheets neatly written with colored ink. Even the complex systems with many elements were tried to make to fit on one single foldable page, and only a low percentage of the keys required - due to the high number nomenclatures - several pages. Effort was made to arrange the elements so that they are easy to use, and can be reviewed with one glance. As these sheets become quickly worn by use, the claves were usually copied on harder and thicker, cardboard-like paper.

There is a variation in sizes, nonetheless. The smallest ciphers only assign signs, letters or numerals to the letters of the alphabet, and they do so sparingly. These are written in Latin, so in addition to assigning not more than one character to each letter, vowels with accents and the letter $k$ are completely missing, and $u$ and $v$ are identical. As a result, often twenty-two or fewer signs are sufficient for the cipher. Needless to mention, these systems are highly vulnerable.

This is why, additions appeared in the sixteenth century. Bigrams are often assigned special signs or numerals, more frequent letters are assigned several ciphers, nomenclatures and nullities turn out to be more common, and it becomes regular that syllables are systematically assigned a symbol. In addition, by the turn of the seventeenth and eighteenth century, the end of our studied period, Latin is often replaced by the national languages, and the special German, French and Hungarian characters are assigned symbols of their own. As a consequence, keys grow to contain over a hundred, sometimes three or four hundred, or even a thousand items.

The appearance of the code keys may vary, but most often they show the letters of the alphabet in the top row, with the corresponding homophones underneath. Syllables, words and nomenclature are listed in 6 to 14 columns, in alphabetical order. It is not unusual to have the meaningless syllables listed and numbered separately from meaningful words and geographical and political names. Nor is it rare to have the names of the months and nullities given separately, in one of the last columns. Sometimes common titles get their code numbers, and these also are often listed separately. This table of Ferenc Rákóczi, a mature and well-defined Latin system illustrates these categories well. ${ }^{15}$ 


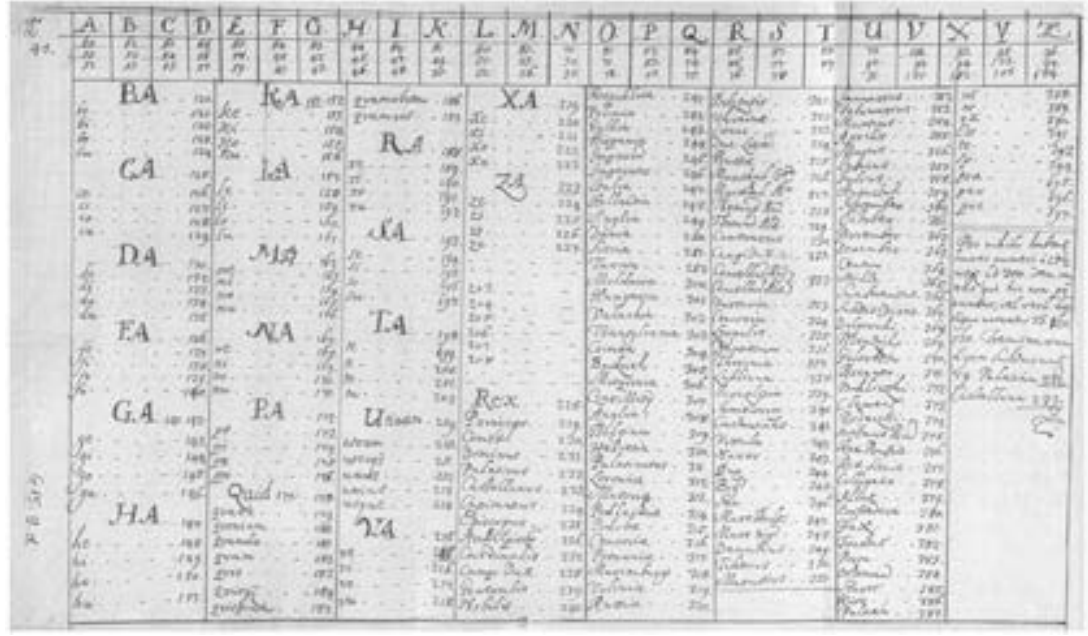

As one goes on to a deeper study of the source material, one has to revise the previous simplified differentiation between the monoalphabetic and the homophonic cipher systems. The transition from the former to the latter was not the result of one big logical step, nor was it a linear evolution. Between the two kinds of ciphers there was a logical progression, but the stages, that may be distinguished, did not necessarily follow each other, but were more or less coexisting:

1. Classic monoalphabetic cipher, in which only letters of the alphabet are assigned a symbol such as in Szapolyai's cipher message to Hieronym Łaski from $1528:^{16}$

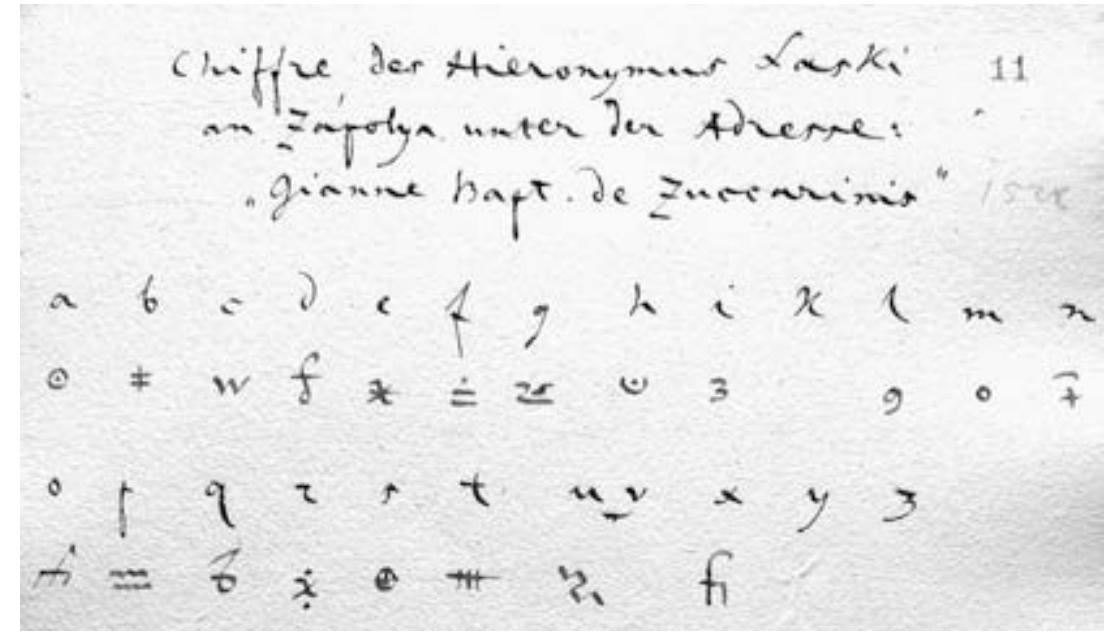


or the key of Jónás Mednyánszky and György Rákóczi II, from 1658: ${ }^{17}$

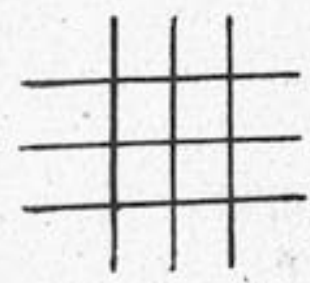

$$
\begin{aligned}
& \text { a. 6. c. a. o. f.g.h.i.k.l.m.n. o. p. }
\end{aligned}
$$

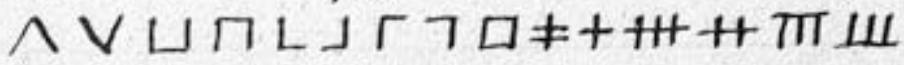

$$
\begin{aligned}
& \text { q. x.t. Z. w. v. x, y. } \\
& \text { 非 } X \equiv 月 \text { 月月日月出。 }
\end{aligned}
$$

The monoalphabetic system occasionally involved fairly "immature" solutions, such as the simple alphabet shift (in its weakest form it is only a shift of one letter, where A becomes b, B becomes c, and C: d,) or when the first and second halves of the alphabet are mutually assigned to each other. These often appeared in the mid-sixteenth-century diplomacy, ${ }^{18}$ as well as in the end of the century in ciphers of the poet Bálint Balassi ${ }^{19}$ but, surprisingly, it was also not outdated enough in the middle of the seventeenth century for Prince György Rákóczi II to use them with his envoys. ${ }^{20}$

17 MNL OL P 497 Mednyánszky family, fasc. 3. Cipher keys, fol. 9.

18 Cipher table of Johann Weze, Archbishop of Lund and Ferdinánd I in 1536-ból: OSZK Quart.

Lat 2254. 29, and the table of Kaspar Seredy and Leonhard von Fels OSZK Quart. Lat 2254. 21.

19 Balassi's cipher will be discussed below.

20 Ágoston Ötvös, Rejtelmes levelek, keys III-VI. See also: Révay, Titkosírások, 76-86. 
2. Monoalphabetic cipher completed with a short list of nomenclatures, such as the table of David Ungnad, Habsburg envoy in Constantinople, ${ }^{21}$ and another table of Jónás Mednyánszky and György Rákóczi II: ${ }^{22}$

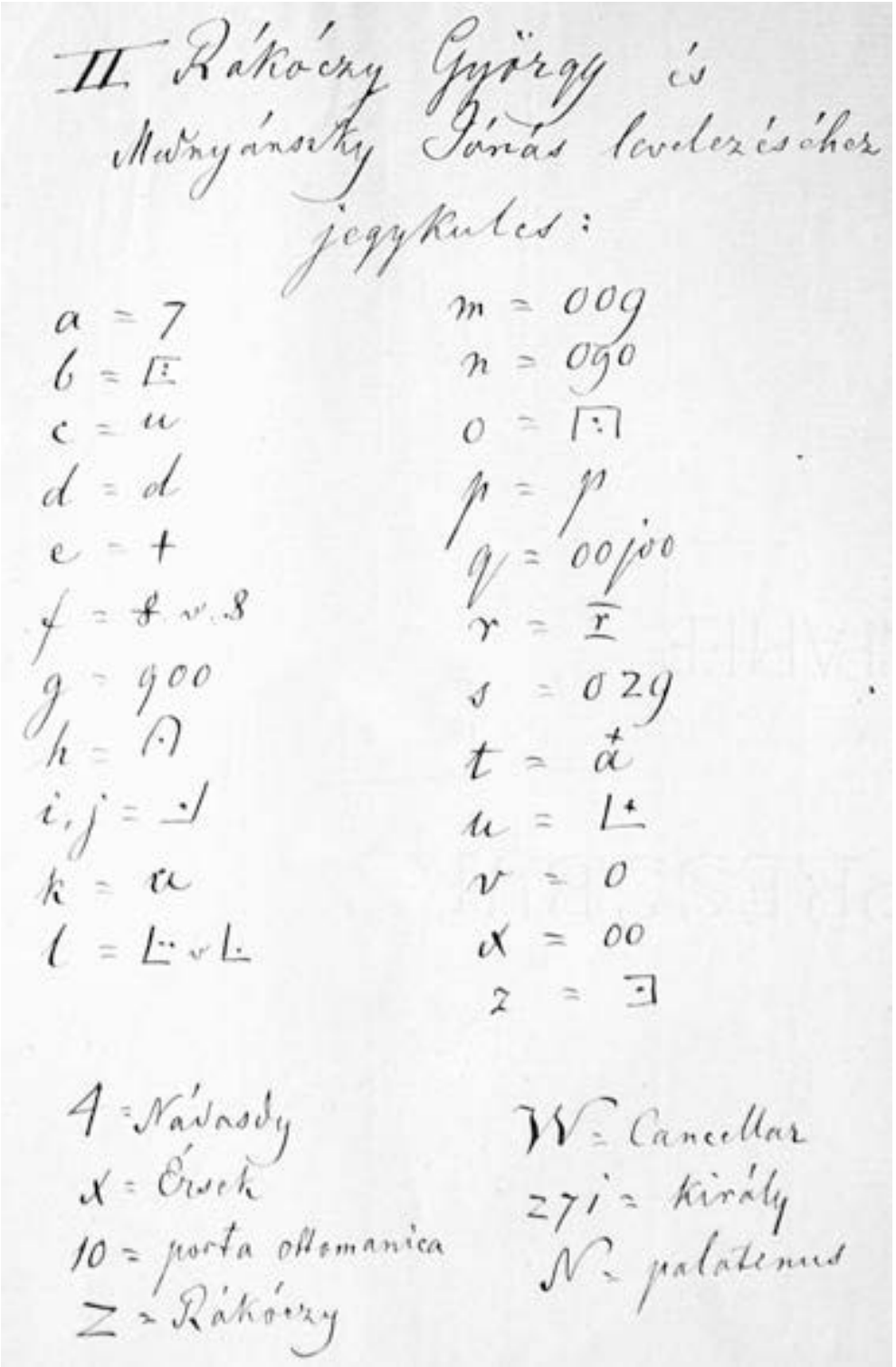


3. Weak homophonic cipher, where only the most frequent vowels are assigned several symbols, with the major part of the alphabet remaining monoalphabetic - such as the clavis of György Martinuzzi, ${ }^{23}$ and that of Ferdinand I from $1530:^{24}$

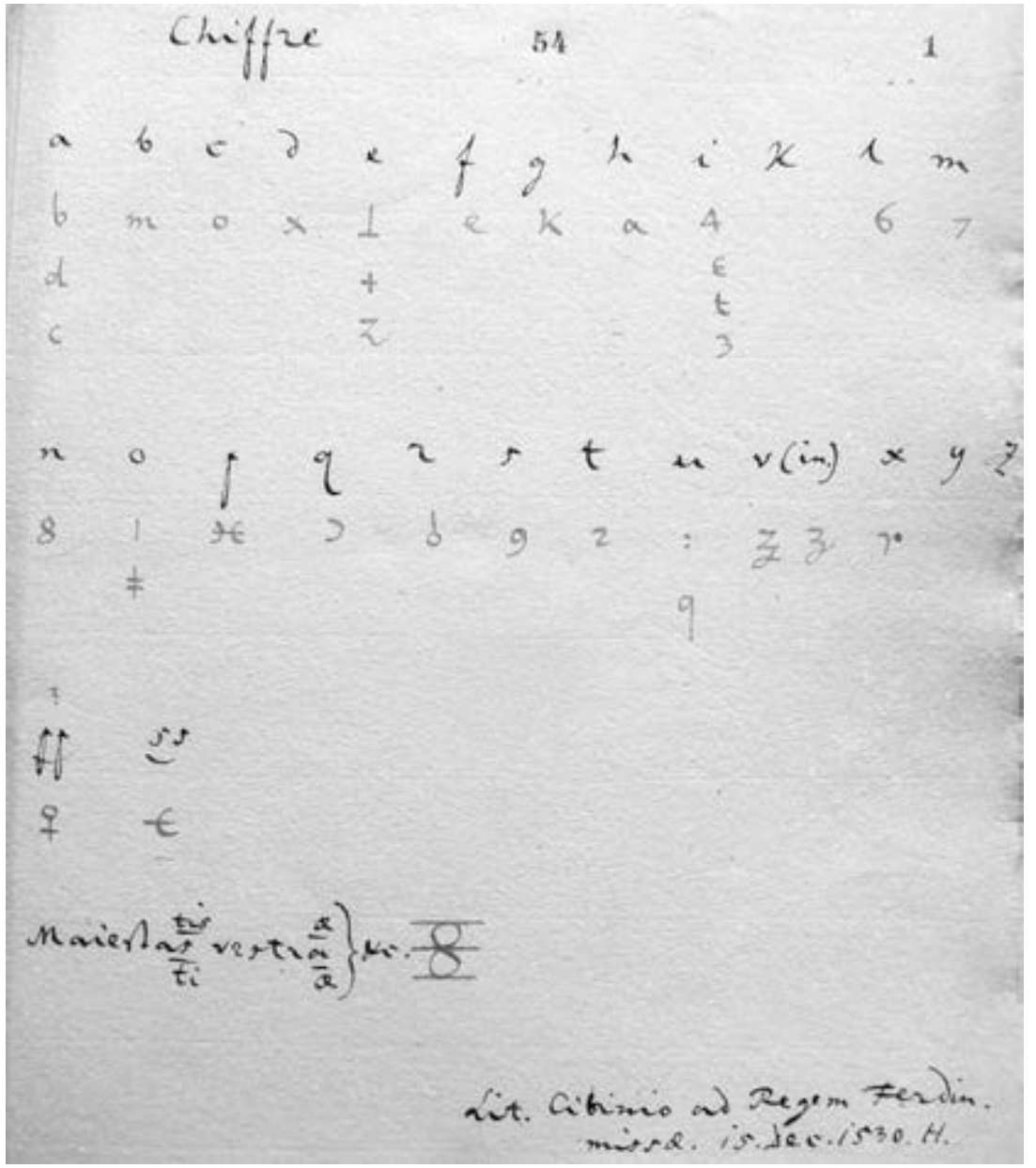

23 ÖStA HHStA Staatskanzlei Interiora Kt. 13. Chiffrenschlüssel: Kt. 13. Nr. 41. fol 133.

24 OSZK Quart. Lat 2254. 1. 
4. Weak homophonic cipher with nomenclatures, such as a key of Andreas Dudith used in messages to the chancellery in Vienna from $1573,^{25}$ and another table of Mihály Teleki: ${ }^{26}$

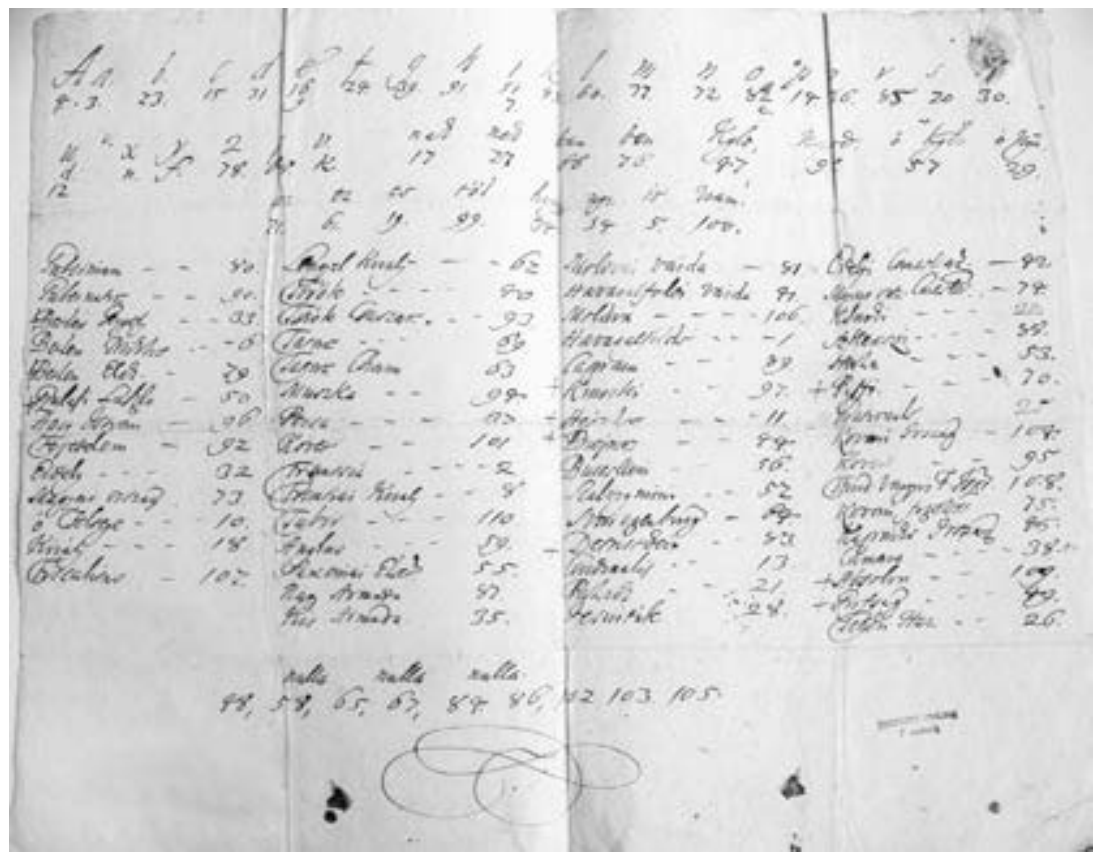

25 Lech Szczucki and Szepessy Tibor, eds. Epistulae / Andreas Dudithius, Vol. 3, 16-17.

26 MNL OL P 497 Mednyánszky family, fasc. 3. Cipher keys. 
5. Mature homophonic cipher (with several symbols assigned to each letter of the alphabet) and nomenclatures, such as the clavis of Mihály Teleki and István Vitnyédi: ${ }^{27}$

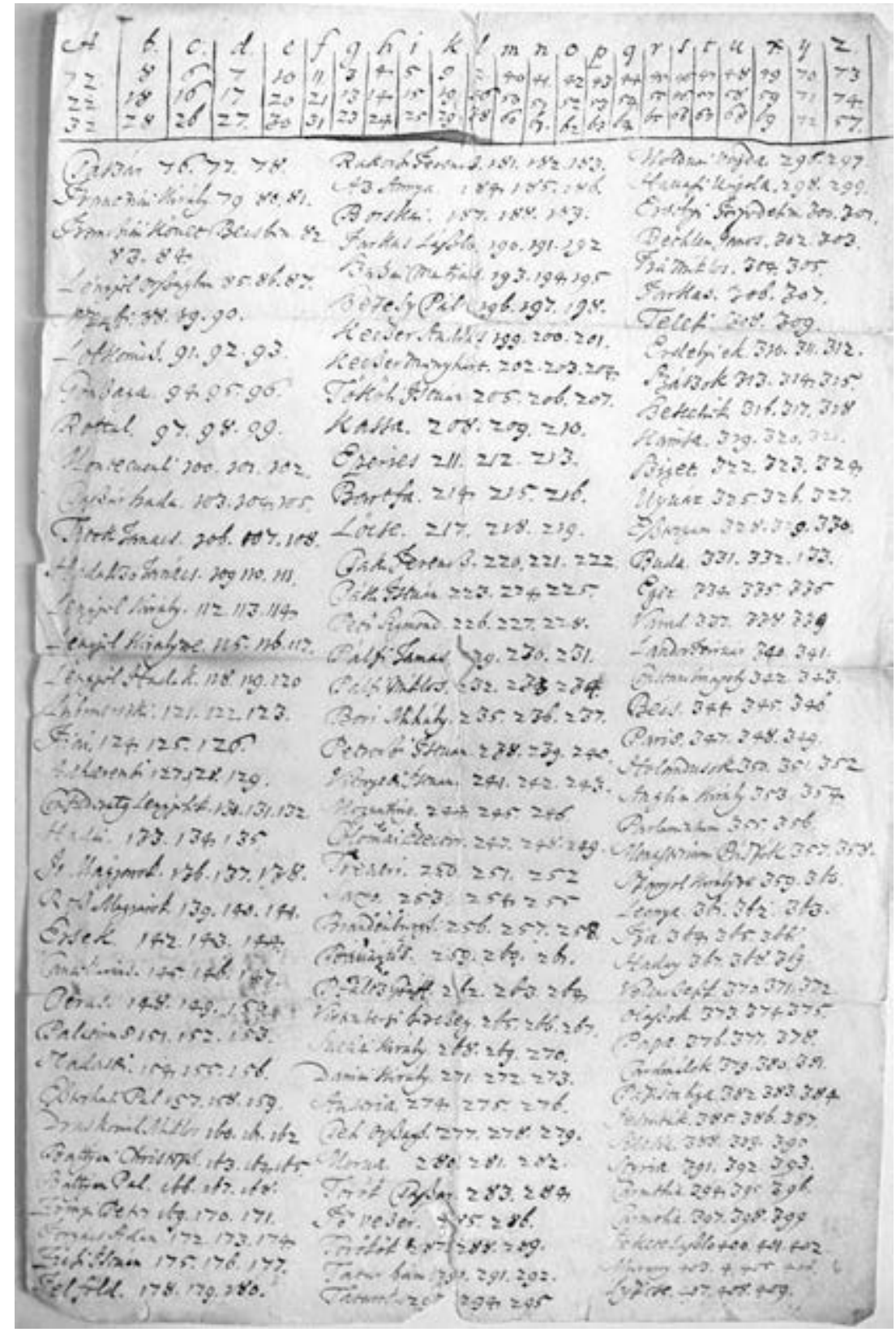


6. Finally, the most detailed homophonic system including nomenclatures, frequent words, nullities, bigrams, and a complete system of syllables as seen in the near 500-item Hungarian cipher system of Ferenc Rákóczi II and Sándor Nedeczky: ${ }^{28}$

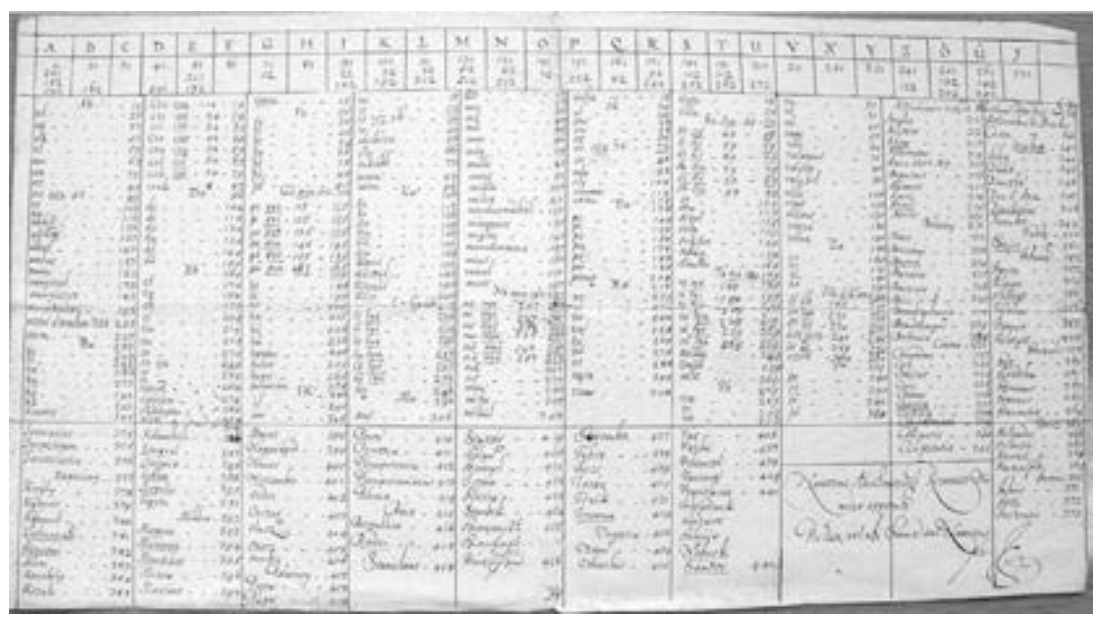

This complex picture is further complicated by two factors. One results from the users being human. A homophonic cipher key may offer several options for each letter in vain if the scribe never made the effort to use other than always the first ones, in which case the method is actually reduced to the level of a monoalphabetic cipher.

The other factor is that the historical development towards a higher level of complexity (from monoalphabetic into homophonic) in reality did not quite respect the six stages that were so nicely outlined above. Some systems used a simple monoalphabetic alphabet, but introduced such a complex system of syllable and nomenclature symbols that in effect the cipher became virtually impossible to break. It also happened that the clavis contained syllables, but no nomenclature, or vice versa, a lot of nomenclatures without any syllables. 
In addition to a growing complexity, we can see another tendency to be formed during this era. In the medieval ages and in the sixteenth century, designers of ciphers seemed to have shared the conviction that the more abstract the signs, the harder it is to break a cipher. Consequently, the dominant cipher of this period is made up of graphic symbols. With time, of course, they realized how difficult it is to design a large number of different symbols - we can experience these difficulties it if we try to come up with four hundred different graphic signs in one sitting - and also that graphic symbols are impossible to arrange in any logical order - something that made the process of decoding infinitely complicated. For this reason, certain modifications were introduced in the structure of the symbols so they can be grouped better (for example the symbols assigned to the letter $A$ all looked somewhat similar), and there was also a growing preference towards numerals instead of graphic symbols. In the international diplomatic correspondence of the Rákóczi freedom fight most keys are numeric, graphic signs occur only in the weaker systems used only for inside communication. ${ }^{29}$ Mixed systems of numerals and graphic signs were rather rare albeit not totally missing.

The advantage of numeric ciphers is their user-friendliness, although this can easily turn into a disadvantage too. In more than one cases, the designer assigned the numbers to the units of the language, the syllables and the nomenclatures in some order. If he was extremely negligent, he also numbered the letters of the alphabet in their original order or backwards, making the task of the codebreaker easy. This can be observed in several claves of Mihály Teleki, ${ }^{30}$ in the correspondence of Ferenc Rákóczi II to his envoy, László Kökényesdi, ${ }^{31}$ and even in several of his claves that he used in writing to the French ambassadors Rivier and Bonnac, channels that we would expect to have employed a more advanced level of technology: ${ }^{32}$

29 War History Archives E. 1705/18, cipher table of Sándor Károlyi and Miklós Bercsényi, and AR I. vol. 4. Appendix, the cipher table of Rákóczi and Bercsényi.

30 MNL OL P 1238 Mihály Teleki's collection, miscellanous documents, cipher keys.

31 MNL OL G 15 Caps. C. Fasc 43. and Ráday Archives C64-4d2-25. 6.

32 MNL OL G 15 Caps. C. Fasc 44. 


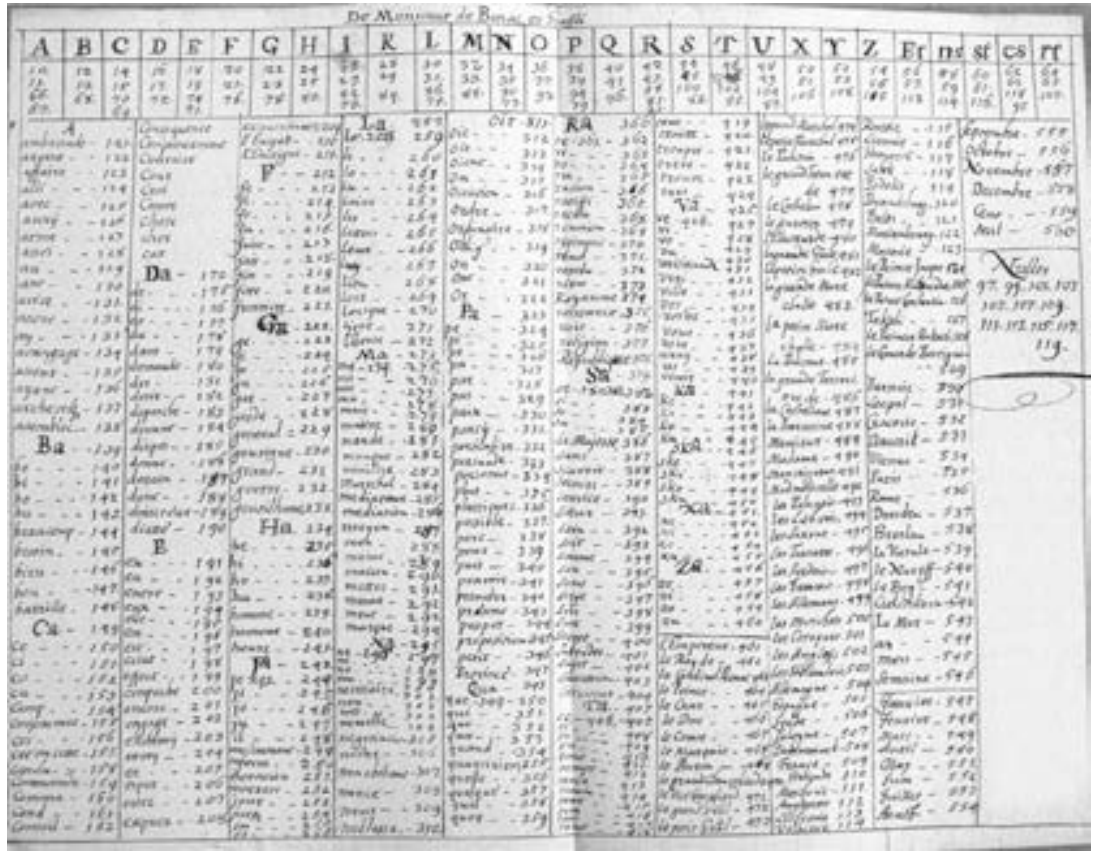

A typical case for a too methodical correspondence is when every letter is assigned ten different numbers, but $\mathrm{A}$ is assigned the numbers from 100 to 109 , B from 200 to 209 , and so on, in a perfectly predictable way. ${ }^{33}$ Once the codee breaker recognizes the system, it is quickly reduced to the level of a monoalphabetic cipher. The above-mentioned Teleki-Vitnyédi clavis faces a similar problem. The key goes like this: A: 2, 22, 32; B: 8, 18, 28; C: 6, 16, $26 .{ }^{34}$ In another, seventeenth century clavis A: 1, 11, 21; B: 2, 12, 22, and E: 5, 15, 25, ${ }^{35}$ and in a third one from the Rákóczi freedom fight A: 25, 50, 75, 100; B: 24, 99, 74, 48, and E: 21, $46,71,96 \cdot{ }^{36}$ The systematic approach is an advantage and a disadvantage at the same time: the cipher is easy to handle and it is just as easy to break.

In most cases, however, the designer was more careful, and the letters of the alphabet are assigned random numbers. The problem is that nomenclatures and syllables are even in such cases numbered as they come in alphabetical order. This enables the addressee to look up geographical or political names assigned to the nomenclature numbers fast, but simplifies the task of the codebreaker too, since he is right to suppose that if 112 is the code

33 Ráday Archives C64-4d2-25. 25.

34 MNL OL P 1238 Mihály Teleki's collection, miscellanous documents, cipher keys.

35 ÖStA HHStA Ungarische Akten Specialia Verschwörerakten VII. Varia, Fasc. 327. Konv. D. Chiffres 1664-1668, fol 15 .

36 Ráday Archives C64-4d2-25. 9. 
sign of absque, 113 stands for aliter, 114 for ante, 115 for autem, 116 for admiral and 118 for Austria, then 117 is more likely to be Anglia than for example Turcica. ${ }^{37}$ Further examples that assign words to numbers in alphabetical order are two claves of Palatine Pál Esterházy, ${ }^{38}$ the famous flower-patterned clavis that Rákóczi used with the French court, and a few of his other tables in which even the letters are assigned to every second number, in a recognizable way. ${ }^{39}$ In case of these cipher structures, even a fifty-percent solution makes the rest of the nomenclature table easy to fill in.

A more clever system is in which the nomenclatures are numbered, not vertically, however, in alphabetical order, but horizontally as they appear on the page. The addressee can decrypt the ciphertext with the same ease, but the hostile codebreaker has a harder task because the numbers do not follow the alphabet but rather the way words were randomly placed next to each other in the columns of the nomenclatures. ${ }^{40}$

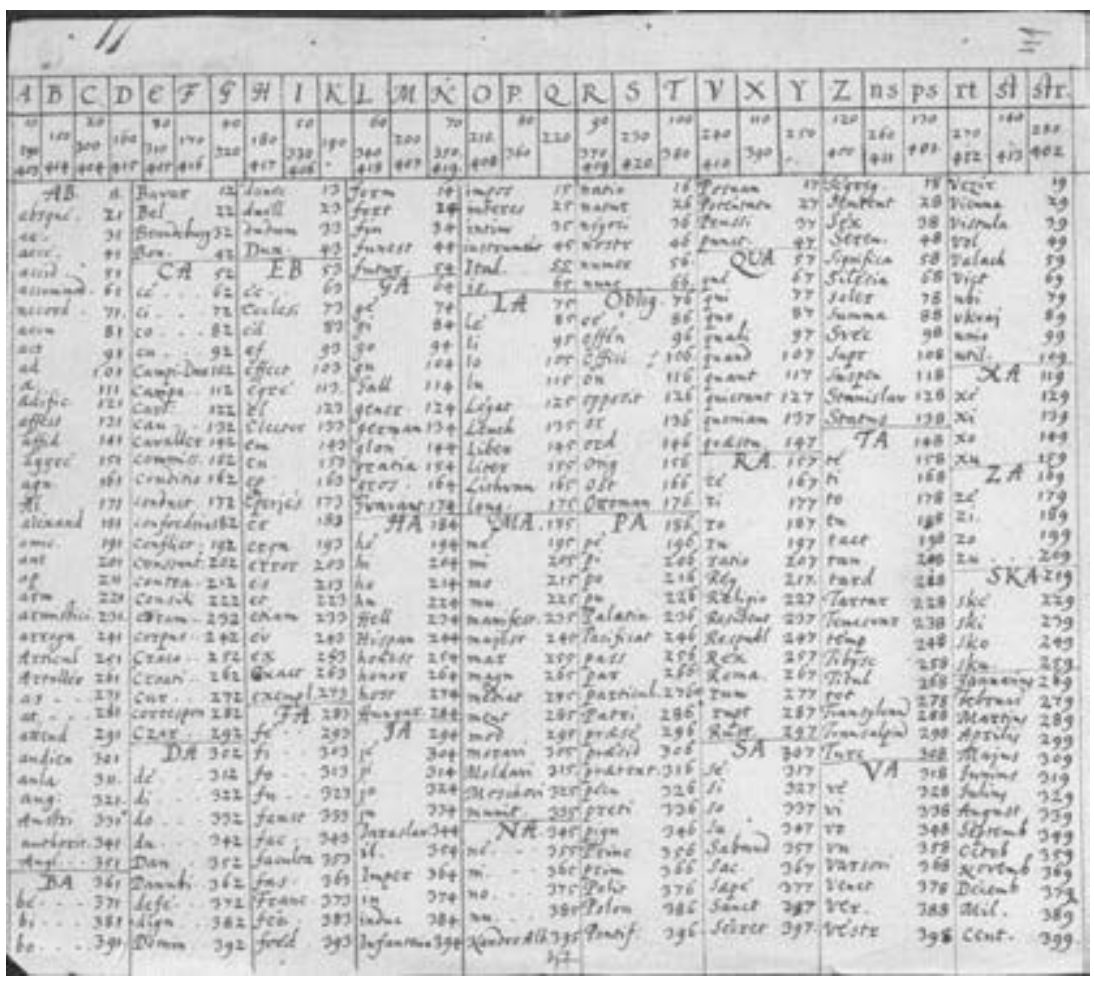

37 MNL OL G 15 Caps. C. Fasc 43.

38 MNL OL P 125 No. 119772.

39 MNL OL G 15 Caps. C. Fasc 44.

40 MNL OL G 15 Caps. C. Fasc 43 and 44. 
Similar problems arise when the different categories of the cipher (letters, syllables, nomenclatures, nullities) are corresponded different types of code signs. For example, letters are always assigned two-digit numbers, and nomenclatures three-digit ones, ${ }^{41}$ or when the system is made up of graphic symbols but the symbols for the nomenclatures look different from the symbols for the letters. ${ }^{42}$ This procedure, which was used in sixteenth-century diplomacy as well as in the Wesselényi movement or the Rákóczi freedom fight, enables the addressee to quickly find the right category in the big and complex table, but it helps the codebreaker just as much, who will be able to differentiate between letters and nomenclatures just by looking at them, and will soon leave the latter out of the frequency analysis.

According to the proper modern terminology: these cipher tables are 'structured'. An advanced stage is represented by the so-called 'unstructured' tables, in which the code words follow each other completely randomly, giving no clue whatsoever to the codebreaker. Entirely 'unstructured' nomenclature tables, nonetheless, are rather rare, especially among the extensive ones.

These problems are partly due to the fact that both encryption and decryption were done by the very same table. There are a few exceptions, when the encryption works with a different type of table than the decryption, and both processes can be optimized to fit their own purposes. The nomenclature words of the encoding table are organized into alphabetical order, while the decoding table is arranged in the order of the code numbers. One A4-size chart of Ferenc Wesselényi (ad scribendum) gives the code numbers of syllables and nomenclatures in alphabetical order, while the other (ad legendum) lists the cipher signs in a numerological order. One system, two different perspectives. ${ }^{43}$ Similarly, a chart of Rákóczi, called reducta, helps the addressee in the decryption process by showing the system from his perspective, whereas another table of the same cipher follows the logic of the encryption. ${ }^{44}$ These double tables, however, are the minority. Most ciphers use one type of table for both processes.

41 OSZK Quart. Lat 2254. 51-52; ÖStA HHStA Ungarische Akten Specialia Verschwörerakten VII. Varia, Fasc. 327. Konv. D. Chiffres 1664-1668, fol 12-13; MNL OL G 15 Caps. C. Fasc 43.

42 OSZK Quart. Lat 2254. 27.

43 ÖStA HHStA Ungarische Akten Specialia, Fasc. 327. Konv. D. Chiffres 1664-1668, fol 1-2.

44 MNL OL G 15 Caps. C. Fasc 43. 
The language of the tables should also be taken into account. Sometimes, when only the letters of the alphabet and maybe a few syllables accompanied by numbers can be seen, it is hard to decide what the original language of the key was. Naturally, since these tables were mostly used by sixteenth-century diplomats, we have reason to think of Latin. In other cases, though, the words of the nomenclature table precisely identify the language.

Latin kept its vital role in cipher tables. At least one third of all extant tables were used for a text written in Latin. In the Hungarian archives, there are not more than two to three percent of Italian claves and only a bit more German. Most of the German ones, by the way, were ciphers caught or broken in the Rákóczi freedom fight. By the end of the early modern period, particularly in the Rákóczi freedom fight, French becomes more dominant - ten percent of all extant tables are in French, and not only in messages directly related to Louis XIV, but in other directions too, for example with the Polish. Thirty percent of all tables are in Hungarian. Their ratio gradually increases by the end of the period. Finally, several claves survived that were apparently used in more than one language, and several others had Latin, Hungarian, and French versions too.

\subsubsection{Letters of the alphabet}

The letters of the alphabet of the open text are most often matched with graphic signs or numbers in code tables. Assigning other letters in the code alphabet to the original letters is not infrequent either. Different parts of a grid can also make a code alphabet, like in the famous Pigpen cipher of the Freemasons. Other examples of this kind are two tables from 1658 of Jónás Mednyánszky and György Rákóczi II. ${ }^{45}$ 


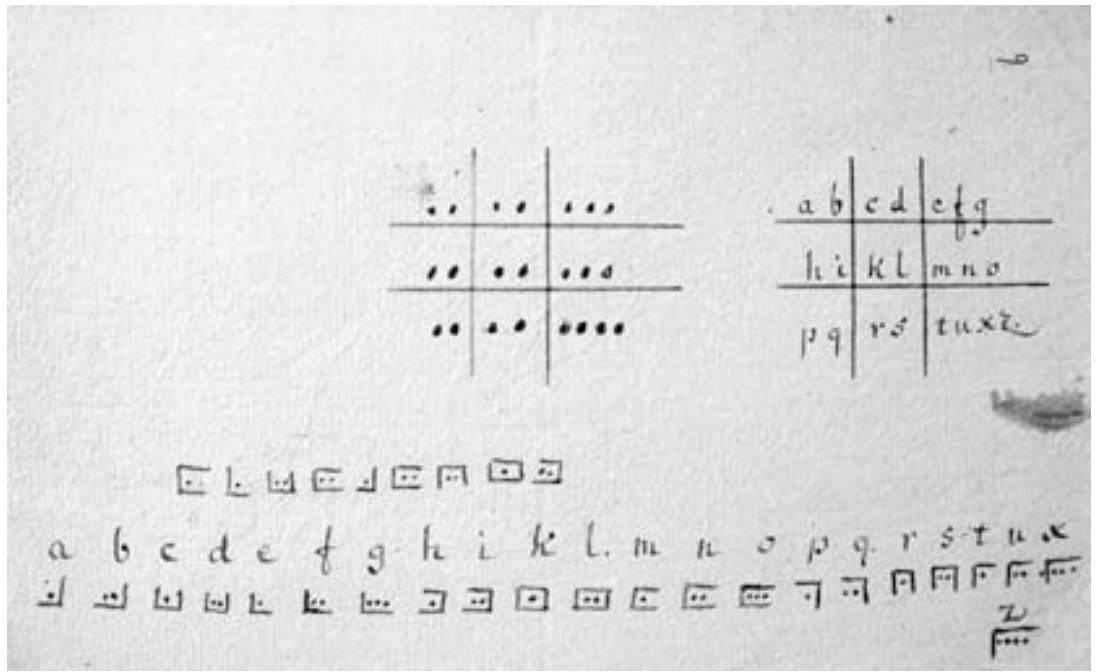

Particularly exceptional, however, is the clavis musicalis of Ferenc Rákóczi II, a three-page nomenclature table that assigns Latin words to political and geographical names, and musical notes to letters. Due to these musical notes, the system is spectacular, but even this does not change the fact that its alphabet remains basically a vulnerable monoalphabetic cipher. $^{46}$ 


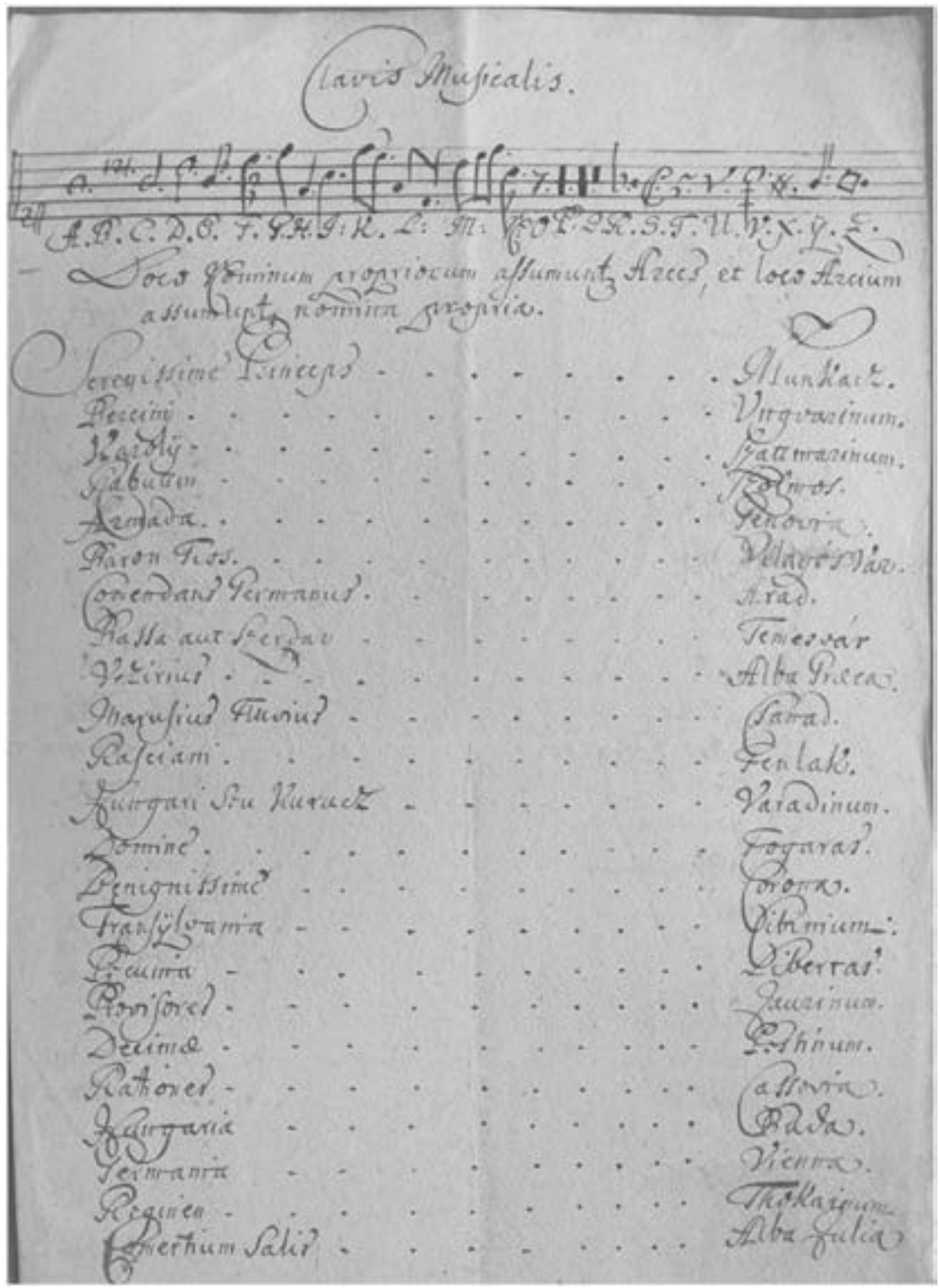

Code alphabets may reflect how the language of the open text functions. When the designers first realized the danger in double letters and tried to hide them by making up a special sign for the most typical ones (in Latin: $r$, $l l, s s)$, they were apparently aware of the recognizable features of the language. Special German characters also appeared relatively early: an example is from around 1570, in the clavis of David Ungnad, the Habsburg court's 
ambassador to Constantinople. ${ }^{47}$ The typically Hungarian letters appear in the tables from the second half of the seventeenth century: first $\ddot{O}$ and $\ddot{U}$, then $T y, S z, N y, C s, C z$ and $L y{ }^{48}$ Curiously enough, the most frequent accentt ed letters, $A$ and $E$ were only assigned special numbers in the beginning of the eighteenth century, by the time $\ddot{O}$ and $\ddot{U}$ were already much used. ${ }^{49}$

\subsubsection{The nomenclatures}

In a recent article cryptology historian David Kahn denotes the systematic study of the development of nomenclatures as one of the tasks to be achieved in the field..$^{50}$ Nomenclatures, this list of proper names and frequent words carries truly valuable information for historians regarding both the political situation of the time and the use of cryptographic technology.

As mentioned above, the code signs of the nomenclatures were visually separated from the rest of the cipher table. In the correspondence of Ferdinand I and Johann Malvezzi, envoy to the Ottoman Porte, for example, single signs are assigned to letters, numbers for double letters, and two- or three-letter words for nomenclatures. ${ }^{51}$ This distinction remains to be quite common later, and is related to the tendency of renaming nomenclatures by other code words. In the correspondence of András Dudith and the Habsburg court, Niger stands for Laski, Accursius for the Pope, and Lethargici for the Lithuanians. ${ }^{5^{2}}$ In a mid-sixteenth-century table Veneti stands for mirantur, Ragusei: insignis, Orator: utinam, Passa: otium, Turchi: paxes. ${ }^{53}$ Free association and some humor were not absent from the name giving procedure.

Most claves of the sixteenth century included only a few, not more than ten to twelve nomenclatures for the most important political and geographical names. The 1531 table of Sigismund Herberstein and Hyeronim Łaski contains merely two nomenclatures: one for Emperor Suleiman and

OSZK Quart. Lat 2254. 23r-v.

48 MNL OL P 1238 Mihály Teleki collection, Miscallenous documents, Cipher keys; ÖStA HHStA Ungarische Akten Specialia, Fasc. 327. Konv. D. Chiffres 1664-1668, fol 16; MNL OL G 15 Caps. C. Fasc 43.

49 MNL OL G 15 Caps. C. Fasc 43.

50 David Kahn, "The Future of the Past," 58.

51 War History Archives, 1548/3.

$5^{2}$ Lech Szczucki, Szepessy Tibor, eds. Epistulae / Andreas Dudithius, Vol. 4, 18-22.

53 OSZK Quart. Lat 2254. 20. 
one for Łaski' lord:János Szapolyai. ${ }^{54}$ The 1545 table of Johann von Tarnow, Polish ambassador to Ferdinand I uses only one: Sigismund junior Ploniae $R e x,{ }^{55}$ and the 1658 table of Jónás Mednyánszky, acting on behalf of Prince György Rákóczi II, only contains seven: Nádasdi, bishop, porta ottomanica, Rákóczy, chancellar, king, palatine.$^{56}$ In the longer tables of the Rákóczi freee dom fight Caesar, Rex and Princeps are often the first words. By the end of the early modern period the lists grew to include several hundred, occasionally a thousand items.

The enrichment of the list of nomenclatures is a good illustration for the growing awareness of the vulnerability of codes. The names of the months are rarely included in the nomenclature lists in the sixteenth century ${ }^{57}$ but they are almost compulsory elements by the time of the Rákóczi freedom fight, because the dates, that always had to be indicated at the beginning or end of a letter, are the most critical part of every enciphered letter where codebreakers can easily find a breaking point. The same is true for numbers in general, punctuation marks, and the obligatory greetings at the beginning of a letter, all of which became part of the nomenclature lists by the end of the seventeenth century. In the table of Rákóczi and Ferenc Horváth, the phrase "Your humble and unworthy servant" is simply 887 , Ferenc Horváth (obviously as a signature) is 888 , the question mark is 1013, and the days of the month from 1 to 31 remain unchanged - a daring and clever invention. Numbers used for other purposes have their own codes, so for example eight is $683 \cdot{ }^{58}$

A close reading of the nomenclature tables serve for painting a vivid picture of the political environment of a period simply by showing who or what was important enough for the corresponding partners to include in the list. They put those names on the cipher table that occurred often enough in the text for a codebreaker to identify them and use the probable word method. The major foreign relationships of Rákóczi can be well mapped out just by looking at the diplomatic cipher tables used during the freedom fight. Another example is a nomenclature table from the correspondence of Mihály Apafi, prince of Transylvania, and palatine Pál Esterházy which shows clearly who and what was important to them: peace, mining towns, Telekij, frontier armies, Tököly, Wesselényi. A mere glance on the keys of the 
Wesselényi movement confiscated by the Habsburg court is informative about the network of the conspiracy, these were indeed the participants: Our graceful Lord Palatine, Lord Nádasdy, Lord Péter Zrínyi, István Csáki, the bishop of Györ, etc. ${ }^{59}$ Naturally, these tables reveal details that had been long known to those who study the period, but it is still fascinating to see how a single-page table can tell us, who were the really relevant figures in a specific historical situation.

There are cases, however, where we can reach more important conclusions based on the nomenclature table. The most detailed table from the Gévay collection (a table that surpasses most eighteenth-century claves in its richness) was apparently not used in a correspondence related to the diplomacy of the Hungarian Kingdom. However developed and clever this cipher may be, the code words themselves prove that they were not connected to Hungarian history in any way. ${ }^{60}$ An even more compelt ling conclusion can be drawn from the choice of nomenclatures of one table of Rákóczi that will be discussed in further detail in a later chapter. This cipher key is completely void of the names of the relevant political figures and military scenes, but it is full of French terms denoting different emotions. Based on the table, and, as we will later see, further external evidence, we have reason to suppose that Rákóczi used the key with his Polish ally and lover, Elżbieta Helena Sieniawska. ${ }^{61}$ In contrast, the table that was supposedly used by him and his lawful wife includes a most traditional, politically relevant nomenclature list - a telling sign that his marriage will not be long-lasting. ${ }^{62}$

\subsubsection{Nullities}

Nullities, code signs with no meaning that were only used to confuse codebreakers, are denoted by several different terms in the tables such as non-valeurs, nullitas, errantes, nihil significantes, superflua. 
It is not uncommon to have ten to twenty consecutive numbers as nullitas for the sake of simplicity, but in more careful tables such as that of Rákóczi and Daniel Ernest Jablonsky systematic descriptions define nullities: for example all numbers with an apostrophe. ${ }^{63}$ Another table by the same people instructs the reader to consider every letter a nullity that is not listed in other parts of the key ${ }^{64}$ In the table of Malvezzi presented above nullities are meaningful Latin words (atque, etiam, cum, idcirco). ${ }^{6}$ In certain cases certain numbers are not only nullities by themselves - they annul the words preceding them in the ciphertext. ${ }^{66}$ Most commonly, though, a few, sometimes a dozen numbers are simply listed in a separate rubric of the table, under the heading numeri nihil significantes.

\subsubsection{Grammatical elements}

Cipher tables traditionally list letters, syllables and nouns. It was a considerable improvement when grammatical categories were taken into account, and specific symbols were introduced for plural, accusative, genitive, dative and ablative. In two systems of Mihály Teleki - both of which are otherwise fully constructed of numbers - the indicators of the grammatical cases are graphic symbols ${ }^{67}$ It is hard to overestimate the significance of this extension. With the introduction of grammatical signs, cipher systems took a step towards artificial languages, then highly popular. I am going to investigate this issue in the chapter on the transfer of knowledge.

63 Ráday Archives C64-4d2-25. 2.

64 Ráday Archives C64-4d2-25. 3.

65 War History Archives, 1548/3.

66 MNL OL P 1238 Mihály Teleki collection, Miscallenous documents, Cipher keys.

67 MNL OL P 1238 Mihály Teleki collection, Miscallenous documents, Cipher keys. 


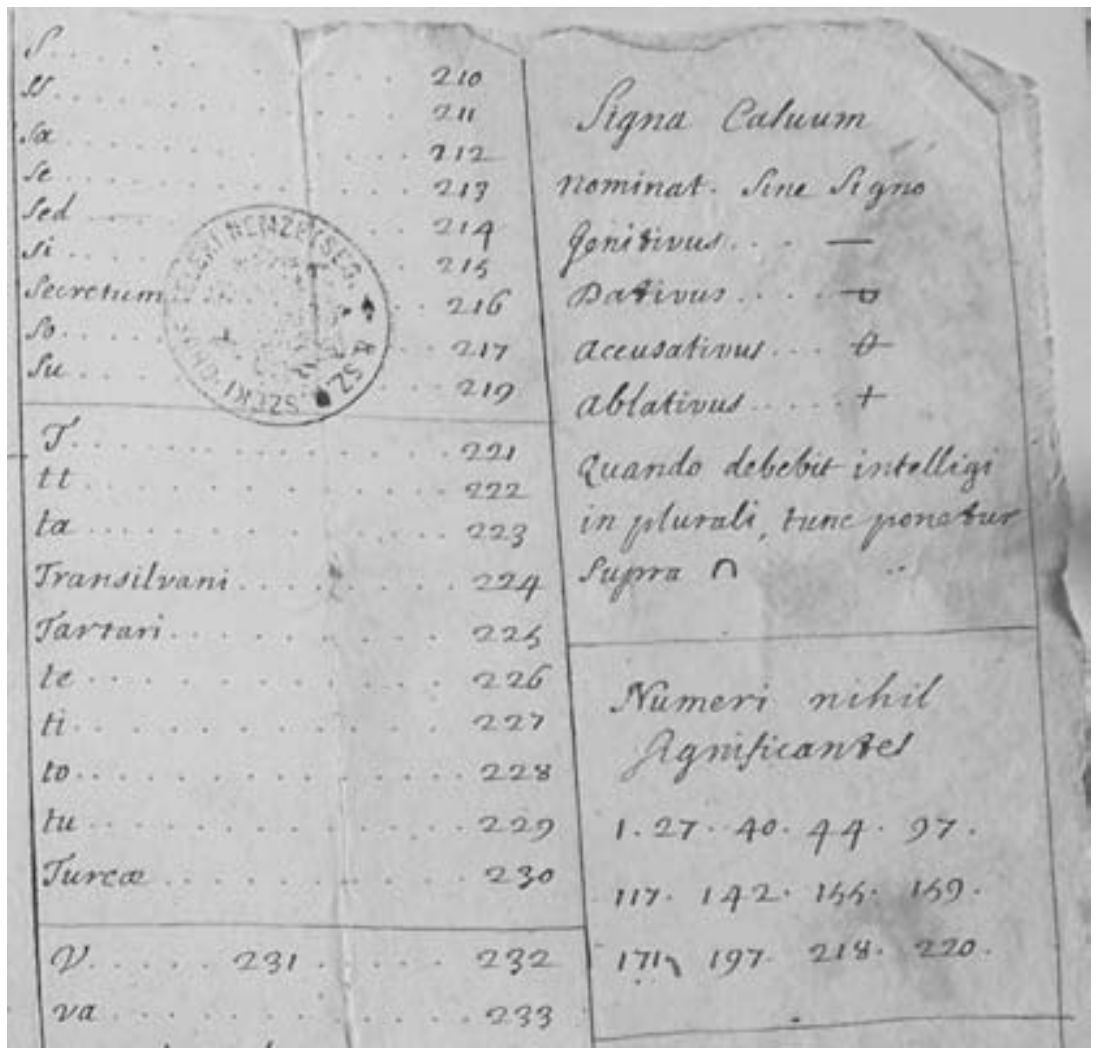

\subsection{Encrypted messages}

There is a striking contrast between the excitement of the readers roused by some novels that contain ciphers, and the usual indifference historians display towards the content of the real enciphered messages. A long row of authors of classic literature, bestsellers and detective stories give a central role in their stories to codes and ciphers - Edgar Allan Poe (The Gold-Bug), Isaac Asimov ( 1 to 999), Arthur Conan Doyle (The Adventure of the Dancing Men), Agatha Cristie (The Four Suspects) Edgar Wallace (Code No. 2.), Umberto Eco (Foucault's Pendulum), Jules Verne (Cryptogram), Dan Brown (The Da Vinci Code), Dorothy Sayers (Have his Carcase) or Ken Follett (Key to Rebecca). ${ }^{68}$ Each issue of the journal Cryptologia contains useful reviews on the recently published secondary literature, and among these, in the "fiction" section it also gives informative reports on crypto-novels and detective stories. 
A recent research lists 150 relatively well-known novels in which ciphers play an important role. ${ }^{69}$

In sharp contrast with this popularity, the extant historical ciphers give a somewhat boring impression. A ciphered message is nothing but a mere sequence of symbols or numbers. Even if the content of the message becomes readable - either because the late addressee had written the solution above the line, or because a modern researcher has reconstructed the key - there are surprisingly few cases which provide information still unknown to the historians specialized on the given age.

Nevertheless, the central thesis of this monograph is that the research on the early modern enciphered messages is relevant from a different aspect. Beyond the content of the secret messages they are rich information resources of their age. The attentive reader can get insight into the attitudes of the people involved, into their notion of secrecy and into the details of their use of technology.

In order to gain the appropriate information from the sources, one either has to examine the original document, or a trustworthy edition of it. Since a portion of the sources ever edited can no longer be found in the archives, and since manuscripts have the disadvantage of not being digitally searchable, source publications, however bad their quality may be, should be included in the research. These source publications are highly different in nature.

The least useful ones for this present research are those that do not indicate which part of the letter was originally enciphered - either because the published text is a regesta (summary), or because this information about the ciphertext did not seem relevant for the nineteenth century editors. Luckily enough this policy was only applied in a small percentage of the text editions..$^{\circ}$

More informative are the editions that indicate (in italics, or in some other way) exactly what part of the text had originally been typeset in chiffre, that is, enciphered. The crypto-historian can thus compare what part of the message was considered worthy of hiding, what words were thought to be dangerous, and what was left as plain text. Scribes often followed awkward strategies and enciphered contents that today we think could easily have been reconstructed on the basis of the rest of the plain text. Another quaint

69 http://www.staff.uni-mainz.de/pommeren/Kryptologie/Klassisch/o_Unterhaltung/Lit/.

70 Such as the correspondence of Ferdinand I and Giambattista Castaldo in: Samu Barabás, "Erdély történetére vonatkozó regesták" (Regestae related to the history of Transylvania) 5-6, Magyar Történelmi Tár, III/15 478-492 and ibid. 651-683. 
observation is how typical the quality and quantity of the enciphered parts within a message are for a given author. Some people cover up only proper names and certain military and financial data, some other encode virtually the complete message.

The majority of publications, for example most volumes of the series Archivum Rákóczianum, set ciphered texts in italics. ${ }^{71}$ Their advantage lies in the fact that both the enciphered parts and the explicit references to the use of cryptography are easily searchable, especially if they are digitized. It is due to this feature that I tried my best to enumerate as many of the published enciphered letters in my constantly growing database as I could. Their disadvantage, however, lies in the fact that they usually contain no information whatsoever on the cipher method employed, with a few exceptions that publish the keys in an appendix, as in an Ágoston Ötvös publication of the enciphered letters of György Rákóczi I ${ }^{72}$ or the modern-day publication of András Dudith's letters. ${ }^{73}$ The average source publication unfortunately does not contain any reference to the method (monoalphabetic, homophonic or other) or to the meaning of the particular numbers and signs, making it impossible to identify the cipherkey. The reason for that in some cases is that instead of the original ciphertext, the publisher used the book of letters that only contained the underlined parts that were to be ciphered. In other words, the publisher himself never actually saw the enciphered message. ${ }^{74}$ More often, nonetheless, the publication was based on the enciphered original, however, the publisher used the reconstructed text that the addressee or his secretary wrote above the lines of the code symbols. Interested mainly in the content of the message, the publisher may have just disregarded the ciphertext.

Finally, the publications most useful for us are those that use skillful and fastidious typesetting to show the code numbers right underneath the corresponding words of the plain text, as in a Károly Széchy publication of Miklós Zrínyi's letters to the prince of Transylvania, ${ }^{75}$ or the published diary of Mihály Bay. ${ }^{76}$

71 AR, vol. I. 2 (Budapest: Magyar Királyi Tudományegyetem, 1872).

72 Ágoston Ötvös, Rejtelmes levelek.

73 Lech Szczucki, Szepessy Tibor, eds. Epistulae / Andreas Dudithius, Vol. 2, 22-23; Vol. 3, 16-17; Vol. 4, 18-19; ibid. 19-20; ibid. 20-22

74 AR, I. vol. 1. 472-474. 13.; 477-478., 16.; 504-506., 35; 512-513., 42.

75 Károly Széchy, ed., Gróf Zrínyi Miklós 1620-1654 (Count Miklós Zrínyi), vols. I-V (Budapest: Magyar Történelmi Társulat, 1896-1902), vol. III, 335-338, vol. IV, 252-268.

76 "Diary of Mihály Bay" in: Kálmán Thaly, ed., Késmárki Thököly Imre és némely főbb híveinek naplói és emlékezetes írásai 1686-1705 (Diaries and memorable writings of Imre Thököly of Kežmarok and some of his main followers 1686-1705), (Monumenta Hungariae Historica, 
Much to the dismay of the historian, the addressee occasionally leaves a few words coded here and there in the ciphertext, and not owning a copy of the key, the editor could not decode these either. ${ }^{77} \mathrm{~A}$ vivid example of this is the following excerpt from a letter of Ferenc Rhédey to Mihály Teleki from 1678: "Our Lord Bethlen and his company, especially Farkas is not writing to Your Lordship as much as he used to, and is not very fastidious in forwarding the letters of the Porte to Your Lordship. Indeed, these days 140. 131. 124. 123. are most evil." ${ }^{78}$ The words most evil were originally in cipher, but were published decoded. However, the preceding numbers, which are apparently nomenclatures and must have stood for the names of particular people, remained in cipher. Modern-day historians are left wondering who Rhédey regarded as most evil. It is not uncommon either to have all the enciphered text of a message unbroken, even though these sources only make up a small percentage of the published letters. ${ }^{79}$

It is symptomatic that in those cases when the late addressee did not decrypt the ciphertext, it has typically remained unbroken for decades or centuries, even if theoretically it was never unbreakable. The author of children's books, Beatrix Potter (1866-1943) wrote her encoded diary between 1881 and 1897, which, though not at all beyond the capacities of a well-prepared codebreaker, was not broken until 1958. Similarly, a typical problem with modern-day publications of Hungarian enciphered texts is that instead of deciphering them, they merely publish those that had been decoded by someone from the time of the ciphertext (most typically the addressee). In case a code was left undeciphered for a few weeks after it was written, it has been most often left undeciphered since then ${ }^{80}$ This is in spite of the fact that the cryptologically informed historian can use mathematical and statistical methods, or - if they are lucky to enjoy the comfort of having the cipher key - they can simply match the ciphertext with the key and thus reconstruct sources previously not available to historians.

When preparing the publication, the editors - but often the addressee himself, whose reading the editor uses - almost always reconstruct the

Magyar Történelmi emlékek 1868, II. 23/2.) 461-578. In the manuscript (MNL OL G. 15. Caps A.1. Fasc 24. fol. 75- 124r.) a hand (a secretary?) wrote the solution above the numbers, on the basis of which the editor amended the text.

77 Teleki 8. 135-140., 123. In the the decoded text, two numbers, 500 and 42, are left undeciphered.

78 Teleki 8. 306-307. 283 .

79 Among others: Teleki 8. 19-20., 20; ibid. 20-21., 21; ibid. 27., 25; ibid. 290-292., 266.

80 Exceptions are the sources in Révay, Titkosírások, in Ötvös, Rejtelmes levelek, and the aboce quoted articles by Péter Tusor, István Vadai and Hanna Vámos, where historical sources are published in modern decoding. 
message, which involves indicating word boundaries not marked in the enciphered text, and differentiating between vowels with and without accent even if the same symbol encoded the letters 'a' and 'á'. In other words, the editor modernizes the text in the editing customs of his own time. This is a necessary procedure in every text edition which aims not at retaining a letter-perfect transcription for linguistic purposes, but rather readability and usability for historical purposes. Still, it is quite evident that aiming at reader-friendliness leads to significant information loss concerning the use of ciphers.

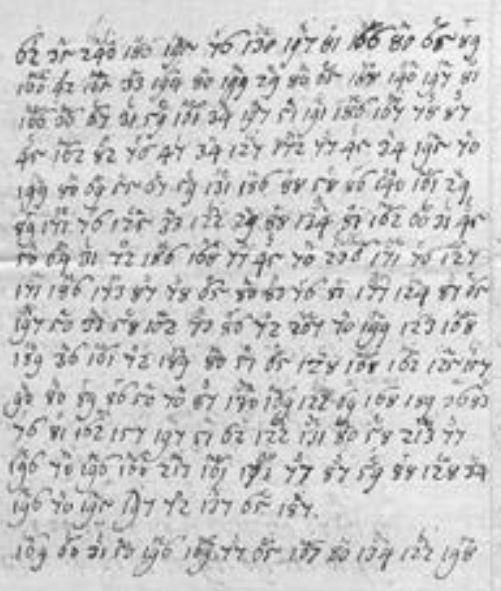

\section{1) mingiar}

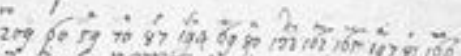

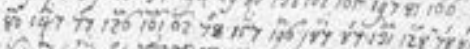
12.

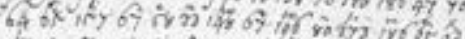

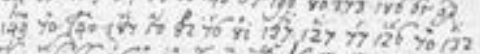

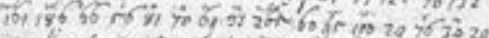

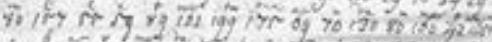

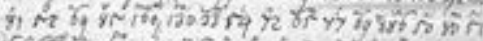

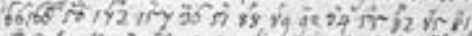

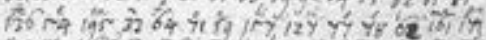

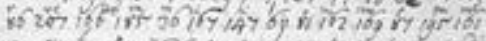

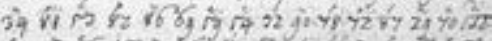
Q

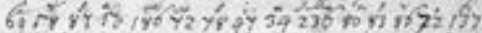

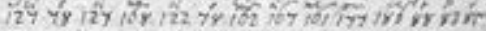

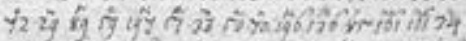

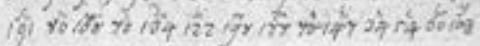

Ciphertext decoded by the addressee: Letter of Rákóczi's French delegate Jean Tournon to Pál Ráday. An advanced homophonic cipher from $1707 .{ }^{81}$

One can get real insight into early modern practice of cryptography through examining the original manuscripts. When the historian starts to make a meaningful message out of a ciphertext by statistical methods or with the help of the key, they will directly realize how hard it is to break a string of symbols when it lacks word boundaries, a correct orthography, and contains a lot of mistakes. 


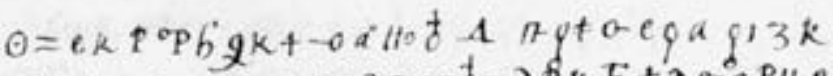

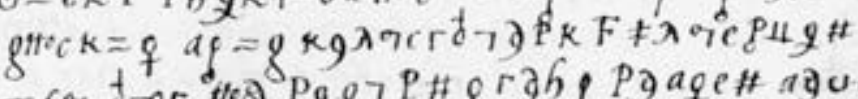

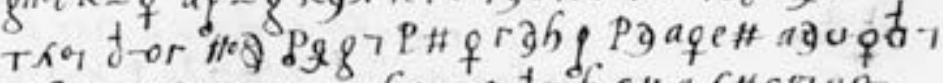

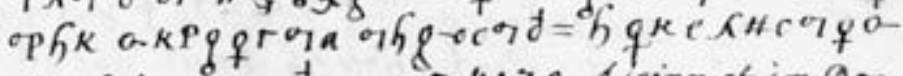

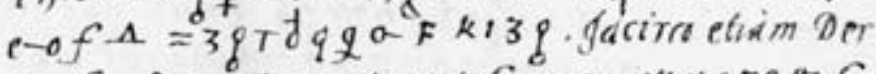

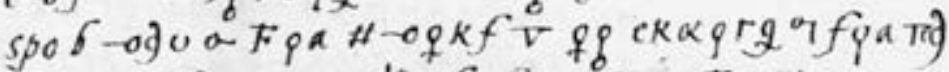

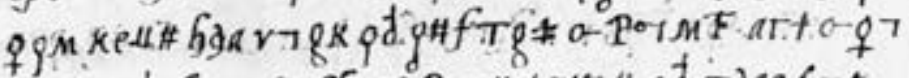
dk $k A+d g h a-a$ off

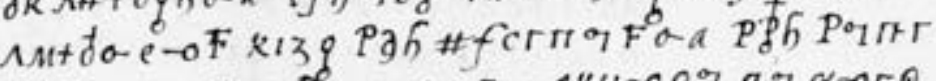

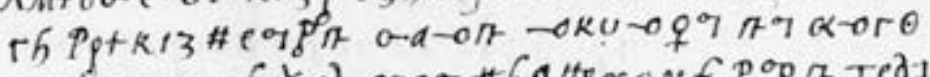

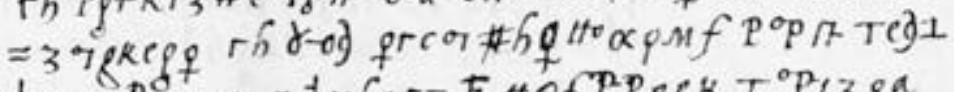

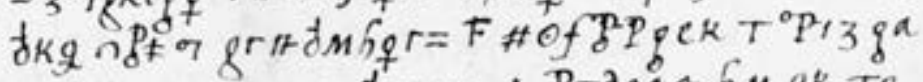

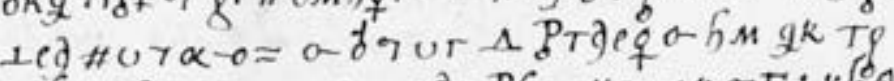

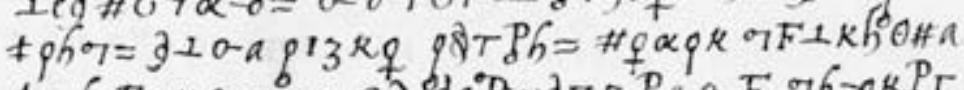

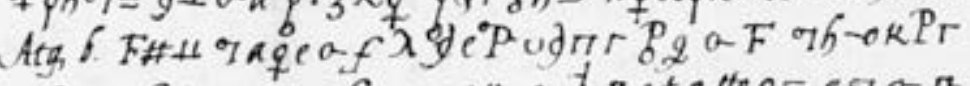

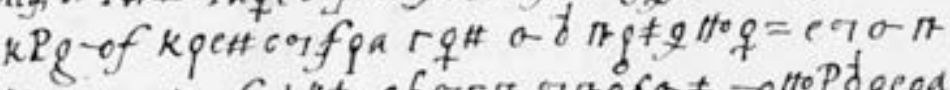

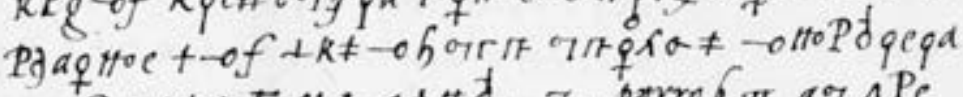

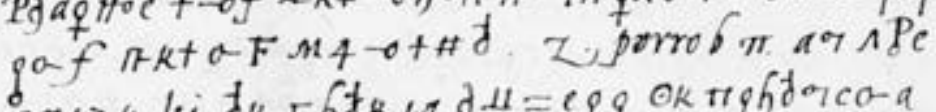

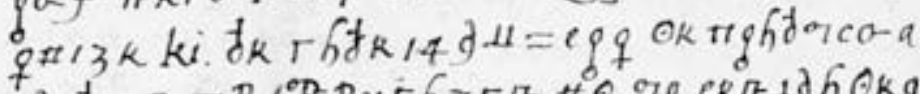

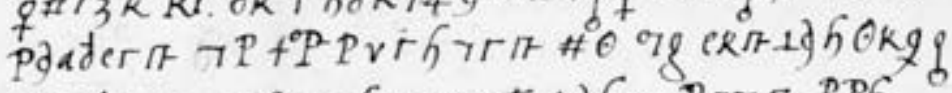

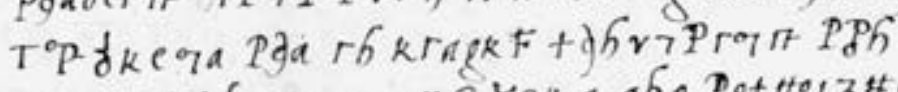

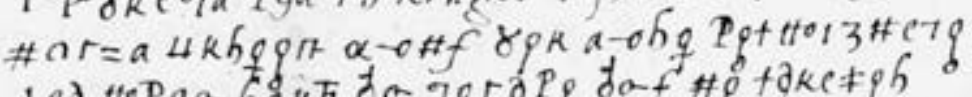

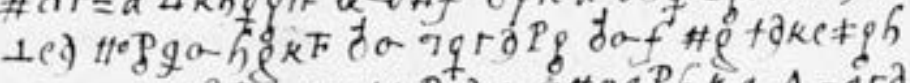

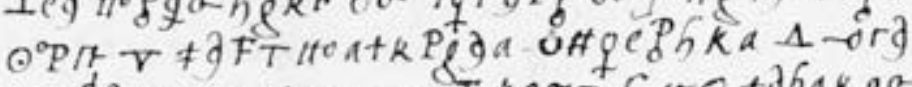

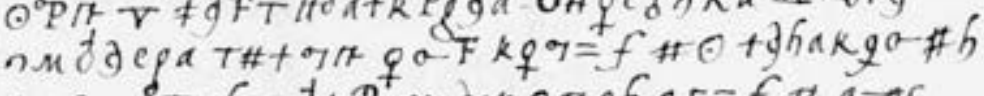

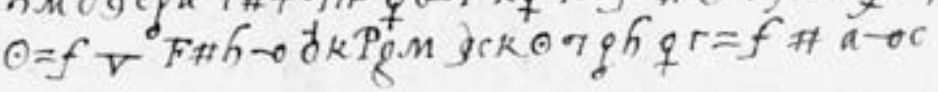




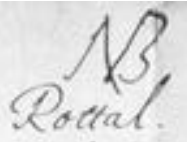

24 is. $z, 70,2,6,27,7,17,8,5$, is $, 5,67,24,1, i \cdot 5$

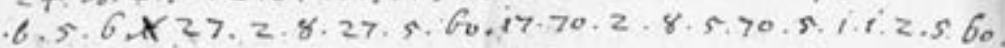
8.5.9.9.2.27.8.5.9.9.2.i7.5.t.5.54.7.24.6.5.9.27 is.

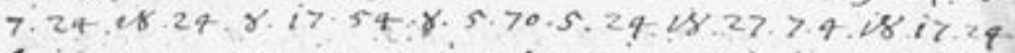
$60.9 .24 .70 \cdot 24.17 \cdot 24,1 \cdot 5 \cdot 8 \cdot 54.5 .70 \cdot 2 \cdot 5 \cdot 1 \cdot 9 \cdot 5 \cdot 8 \cdot 17$ 6. 77.60 .34 .8 .4 .7 .70 .24 .1 .24 .27 .27 .2 .24 .59 .8$.

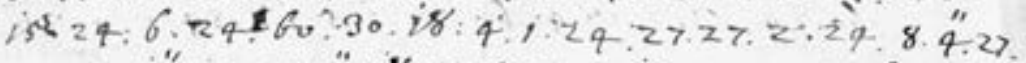

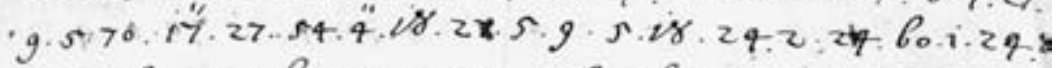

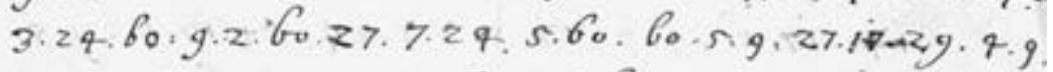

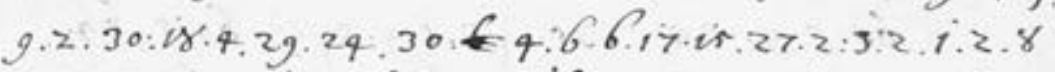
5.9.3.5. 64.17 .4 .9 .60 .5 .54 .80.5.9.7.24.28.24.9. it.

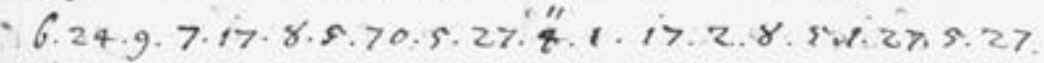

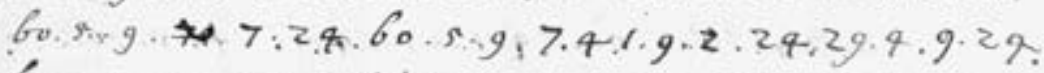
6.2.5.27.54.5.1.5.27.60.5.54.54.5.70.2.5. g.5.8. $17 \cdot 6.24 \cdot 9 \cdot 9.24 \cdot 1 \cdot 54.17 \cdot 36.24 .6 .54 .4 .29$ $60.4 \cdot 9 \cdot 54 \cdot 2 \cdot 27 \cdot 9 \cdot 5.70 .17 .24 .1 .1 .4 .54 .7 \cdot 70.2$ 8.5.70.2.5.6. i.5.54.60.519. is. $2.60 .18 .5 \cdot 6.27$ 6. 5.9:24.29:4:9:24.60.2.5.6.27:7:2.4.60.5:9. 17.6.24.9.7.4.28. $17.29 .1 \cdot 4: 54.4: 27.5 .1 .5$. g.5.6. 27 is 5.1.5.27.5.g. 36.4 .27 .27 .29 .2 .70 .54 5. 8. 17.24 .70 .2 .4 . $54.8,5.60 .27 .2 .60 .27 .5 . B_{0}$

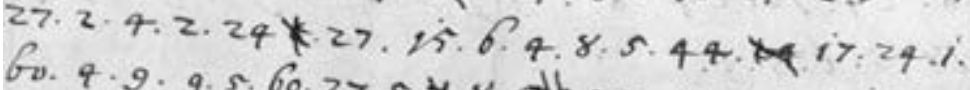

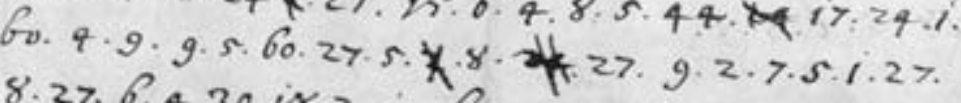
8.27.6.4.30.if.2. $3: 6.24 \cdot 9 \cdot 9 \cdot 2 q \cdot 1 \cdot 8 \cdot 5 \cdot 9 \cdot 3 \cdot 5$. 2.5.8.5.54.54.2.60.5.54.5. ir.5.60.4.6.24. 3.24.60. 30.17.6. : .5.6.q.9. $24.1 .27 .2 q \cdot 1$. $2 \cdot 6.27 \cdot 24 \cdot 9 \cdot 24 \cdot 18 \cdot 4 \cdot 60 \cdot 39 \cdot q \cdot i \cdot 70 \cdot q \cdot 27$

A recently deciphered ciphertext with numbers: A letter from the Wesselényi movement. A monoalphabetic cipher. $^{83}$ 
An experience with such ciphertexts helps appreciate the kind of obstacles addressees were faced even with the legitimate cipherkey at hand, why they had spent the whole night decoding a letter, why they could sometimes be uncertain whether they had used the right clavis, and how they could misunderstand the ciphered text so often. Similarly, one needs to have the manuscript at hand when one tries to reconstruct if these methods could stand against the most frequent codebreaking approach, the probable word method. In reconstructed editions the messages containing the same words are identical, though not necessarily in the original manuscripts. One can also observe if the given code numbers are identical too, making it easy for the codebreaker to use the probable word method, or if he had broken identical words into different syllables each time, or had always assigned a different homophone for the letters to give the codebreakers a tough job. In addition, published sources do not display nullities, but the manuscripts indicate precisely that less diligent encoders tended to place the meaningless numbers at the beginning and end of each row, something that codebreakers must have quickly found out about. Furthermore, in the manuscripts one can see how long a scribe used the same key, how many different keys an important politician applied with his or her correspondents, or to which extent the user (a secretary, but sometimes the prince himself) exploited the capabilities of the enciphering method. Finally, one has to go back to the archival sources too in order to see at what pace the awkward systems of graphic symbols were replaced by the more advanced, number-based methods. A text edition says nothing about how much more sophisticated encoding Rákóczi had used in his letters to the French ambassador than to his general Bercsényi - it simply publishes the messages. 
